Article

\title{
New Pharmacological Strategies against Pancreatic Adenocarcinoma: The Multifunctional Thiosemicarbazone FA4
}

\author{
Dario P. Anobile ${ }^{1,2}$, Mauro Niso ${ }^{3}$, Adrian Puerta ${ }^{2,4}\left(\mathbb{D}\right.$, Stephanie M. Fraga Rodrigues ${ }^{2}$,

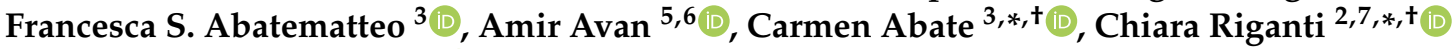 \\ and Elisa Giovannetti $2,8, *,+\mathbb{D}$
}

\section{check for}

updates

Citation: Anobile, D.P.; Niso, M.; Puerta, A.; Fraga Rodrigues, S.M.; Abatematteo, F.S.; Avan, A.; Abate, C.; Riganti, C.; Giovannetti, E. New Pharmacological Strategies against Pancreatic Adenocarcinoma: The Multifunctional Thiosemicarbazone FA4. Molecules 2022, 27, 1682. https://doi.org/10.3390/ molecules27051682

Academic Editor: Drazen Raucher

Received: 29 December 2021

Accepted: 2 March 2022

Published: 4 March 2022

Publisher's Note: MDPI stays neutral with regard to jurisdictional claims in published maps and institutional affiliations.

Copyright: (C) 2022 by the authors. Licensee MDPI, Basel, Switzerland. This article is an open access article distributed under the terms and conditions of the Creative Commons Attribution (CC BY) license (https:// creativecommons.org/licenses/by/ $4.0 /)$.
1 Department of Oncology, University of Torino, Via Santena 5/bis, 10026 Torino, Italy; dario.anobile@edu.unito.it

2 Department of Medical Oncology, Amsterdam UMC, VU University, Cancer Center Amsterdam, De Boelelaan 1117, 1081HV Amsterdam, The Netherlands; apuertaa@ull.edu.es (A.P.); s.m.fragarodrigues@amsterdamumc.nl (S.M.F.R.)

3 Dipartimento di Farmacia-Scienze del Farmaco, Università degli Studi di Bari ALDO MORO, Via Orabona 4 70125 Bari, Italy; mauro.niso@uniba.it (M.N.); francesca.abatematteo@uniba.it (F.S.A.)

4 BioLab, Instituto Universitario de Bio-Orgánica “Antonio González" (IUBO-AG), Universidad de La Laguna, c/Astrofísico Francisco Sánchez 2, 38206 La Laguna, Spain

5 Basic Medical Sciences Institute, Mashhad University of Medical Science, Mashhad 91886-17871, Iran; avana@mums.ac.ir

6 Metabolic Syndrome Research Center, Mashhad University of Medical Science, Mashhad 91886-17871, Iran

7 Interdepartmental Research Center of Molecular Biotechnology, University of Torino, 10126 Torino, Italy

8 Fondazione Pisana per la Scienza, Via Ferruccio Giovannini 13, 56017 San Giuliano Terme, Italy

* Correspondence: carmen.abate@uniba.it (C.A.); chiara.riganti@unito.it (C.R.); e.giovannetti@amsterdamumc.nl (E.G.)

+ These authors contributed equally to this work.

\begin{abstract}
A new sigma-2 ( $\sigma 2)$ receptor ligand (FA4) was efficiently synthesized and evaluated for cytotoxic, proapoptotic, and antimigratory activity on pancreatic ductal adenocarcinoma (PDAC) primary cell cultures, which restrained the aggressive and chemoresistant behavior of PDAC. This compound showed relevant antiproliferative activity with half maximal inhibitory concentration (IC50) values ranging from 0.701 to $0.825 \mu \mathrm{M}$. The cytotoxic activity was associated with induction of apoptosis, resulting in apoptotic indexes higher than those observed after exposure to a clinically relevant concentration of the gemcitabine, the first-line drug used against PDAC. Interestingly, FA4 was also able to significantly inhibit the migration rate of both PDAC-1 and PDAC-2 cells in the scratch wound-healing assay. In conclusion, our results support further studies to improve the library of thiosemicarbazones targeting the $\sigma-2$ receptor for a deeper understanding of the relationship between the biological activity of these compounds and the development of more efficient anticancer compounds against PDAC.
\end{abstract}

Keywords: multifunctional thiosemicarbazone; $\sigma-2$ receptor ligands; pancreatic cancer primary cultures; chemoresistance; migration

\section{Introduction}

Pancreatic ductal adenocarcinoma (PDAC) represents about 95\% of all types of pancreatic cancer and is characterized by an aggressive biological behavior and dismal prognosis. The global burden of PDAC has more than doubled over the past 25 years, and it is predicted to become the second cancer-related death reason in $2040[1,2]$.

Five-year survival rates have just reached about $10 \%$, but therapeutic options are limited, and often patients develop resistance to the standard treatments based on gemcitabine [3].

In the attempt to identify new vulnerabilities to overcome chemoresistance, the socalled sigma ( $\sigma-1$ and $\sigma-2)$ receptors have attracted special interest, because they are 
overexpressed in several tumors, including PDAC, compared to healthy tissues, and their ligands trigger cancer cell apoptosis by pleiotropic mechanisms, including intracellular calcium oscillation, endoplasmic reticulum stress, and alteration of mitochondrial polarization $[4,5]$. The $\sigma 1$ receptor has been defined as a pluripotent modulator mainly residing in the mitochondria-associated ER membrane (MAM) where it exerts its functions through protein-protein interactions [6]. The $\sigma 2$ receptor has only recently been identified as the TMEM97 protein. Its crystal structure has been resolved, helping in the understanding of the ligand-protein interaction and paving the way for more in-depth investigations of the protein biological functions [7,8]. Of note, 20-(S)-hydroxycholesterol has been identified as an endogenous interactor of $\sigma 2$ receptor/TMEM97 [9].

Recently, Niso and collaborators have evaluated the anticancer activity of a series of $\sigma 2$ receptor agonists belonging to the thiosemicarbazone family (including the FA4 compound) in immortalized cell lines, both in vitro and in vivo. Of note, these ligands were also able to induce apoptosis in the human PDAC cell lines AspC1, MiaPaCa2, and PANC-1 in the low micromolar range [10]. $\sigma-2$ receptor agonists have been shown to induce apoptosis with limited toxicities in different preclinical models and, thus, are a promising possibility to trigger apoptosis or autophagy when chemoresistance to traditional therapies is developed [11,12].

Starting from this basis, our work aimed to further validate the effects of the betterperforming thiosemicarbazone, namely FA4, in patient-derived primary cell cultures (PDAC-1 and PDAC-2), which are ex vivo cell populations recovered directly from fresh surgically resected samples from PDAC patients. These cells have the advantage of preserving the most important patient features because they are cultured in vitro for a few passages, in order to maintain the genetic hallmarks of the primary originator tumors [13]. Moreover, bioinformatic studies conducted in our laboratory highlighted that the gene coding for the $\sigma-2$ receptor was overexpressed in the PDAC- 1 and PDAC-2 cells compared to the normal immortalized pancreatic ductal cells HPDE. These models were used to further establish the cytotoxic and proapoptotic effects of FA4, as well to investigate its inhibitory effects on cell migration.

Remarkably, we found that in both PDAC1 and PDAC2, the IC50 of the FA4 compound was lower than the one reported in cancer immortalized cell lines, suggesting that the compound also exerts a good cytotoxic activity in primary cell cultures. This effect was associated with apoptosis induction, which was comparable to the proapoptotic effects of gemcitabine, a drug commonly used in the treatment of PDAC [14].

As for the second objective of our study, FA4 has been shown to exert antimigratory effects and could, therefore, provide new opportunities for therapy against the pro-invasive and metastatic behavior of PDAC [15].

\section{Results}

\subsection{TMEM97 mRNA Expression in Pancreatic Cancer Primary Cells}

Our next generation sequencing (NGS) transcriptomic data showed that the $\sigma-2$ receptor mRNA TMEM97 was expressed in both primary pancreatic cancer cell culture, at significantly higher values compared to the normal human pancreatic ductal epithelial HPDE cells (Figure 1). These results were in line with previous findings, demonstrating a higher expression of the $\sigma 2$ receptors on the plasma membranes of PDAC cell lines compared to HPDE cells (Supplemental Figure S1) [10]. Of note, the highest Fragments per Kilobase Million (FPKM) value was measured in PDAC-2 cells (Figure 1), which originated from the most clinically aggressive tumor [16].

\subsection{FA4 Synthesis}

FA4 was obtained according to a polypharmacology strategy, following other $\sigma 2$ receptor-targeting thiosemicarbazones (e.g., MLP44 and PS3) that had shown promising antitumor properties in a panel of immortalized human PDAC cells and in a murine (KP02) tumor model $[17,18]$. All these thiosemicarbazones were designed with the aim to bind 
$\sigma-2$ receptors, that are overexpressed in a number of cancers $[19,20]$, and chelate metals (in particular iron and copper ions) in order to obtain synergic effects by adding the effects of the alteration of the redox state of cells due to metal chelation to the cytotoxic properties proper of the $\sigma 2$ agonists [21].

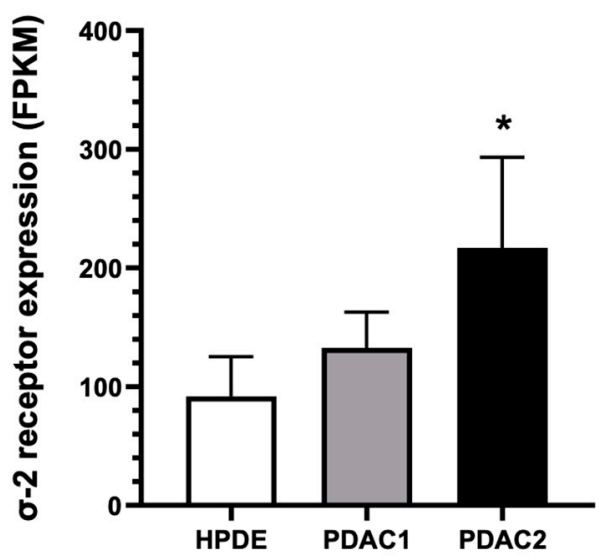

Figure 1. Two primary pancreatic cancer cell cultures (PDAC-1 and PDAC-2) originated from patients undergoing surgical resection for PDAC showed significantly higher mRNA expression levels of the $\sigma 2$ receptor compared to HPDE cells. Columns represent the mean values obtained from three independent experiments; bars represent the SD. * $p<0.05$ compared to HPDE cells.

FA4, which was designed based on the $\sigma 2$ reference agonist siramesine, demonstrated a superior anticancer activity in a panel of PDAC cells in comparison with its congeners MLP44 and PS3, that only differ in the basic moiety, with the (Z)-N,N-dimethyl-2-(2oxoindolin-3-ylidene)hydrazinecarbothioamide unchanged (Figure 2).<smiles>CN(C)C(=S)N/N=C1\C(=O)N(c2ccccc2)c2ccccc21</smiles>

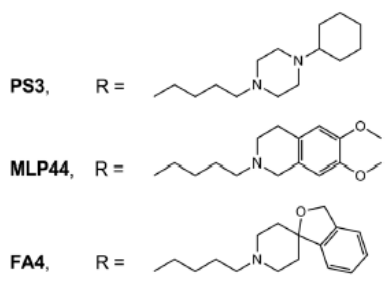

Figure 2. Chemical structures of the thiosemicarbazones (MLP44, PS3, and FA4) targeting the $\sigma 2$ receptor.

The results obtained in commercial PDAC cell lines [10] highlighted how the basic moiety 3H-spiro[isobenzofuran-1, $4^{\prime}$-piperidine] of FA4, which differs from the 6,7dimethoxytetrahydroisoquinoline in MLP44 or the 1-cyclohexylpiperazine in PS3, may drive this increased activity. While MLP44 and PS3 underwent a deconstruction approach in order to evaluate how the chelating moiety impacts on the $\sigma$ receptor affinity and overall activity, this was not investigated for FA4. Indeed, the removal of the thiosemicarbazone moiety importantly reduced the cytotoxic activity of MLP44 and PS3 [10]. Thus, FA4 was deconstructed by removing the thiosemicarbazone moiety, resulting in compound MT8 that appears like a simplified isomer of the siramesine, in which the butyl linker is in position-1 rather than position-3 of the indole ring, devoid of the $p$-fluorophenyl portion.

According to a previously reported procedure [17], the synthesis of compound MT8 was obtained by nucleophilic substitution of the spiropiperidine system on the 1-(4chlorobutyl)- $1 H$-indole portion (Scheme 1 ).

The compounds underwent radioligand binding assays on $\sigma 1$ and $\sigma 2$ receptors, according to the previously adopted protocols $[17,18]$. While the affinity for the $\sigma 2$ receptor was subnanomolar $\left(K_{\mathrm{i}}=0.43 \mathrm{nM}\right.$, Table 1$)$, for $\mathbf{M T 8}$, the affinity for the $\sigma-1$ receptor was in the two-digit nanomolar range $\left(K_{\mathrm{i}}=27.3 \mathrm{nM}\right.$, Table 1$)$ : this compound was a moderately 
selective high-affinity $\sigma-2$ receptor ligand, with an improved profile compared to siramesine that, from our perspective, did not discriminate between the two $\sigma$ subtypes $\left(K_{\mathrm{i}}=10.5 \mathrm{nM}\right.$ for $\sigma 1$ and $K_{\mathrm{i}}=12.6 \mathrm{nM}$ for $\sigma 2$ receptors, respectively) [22].

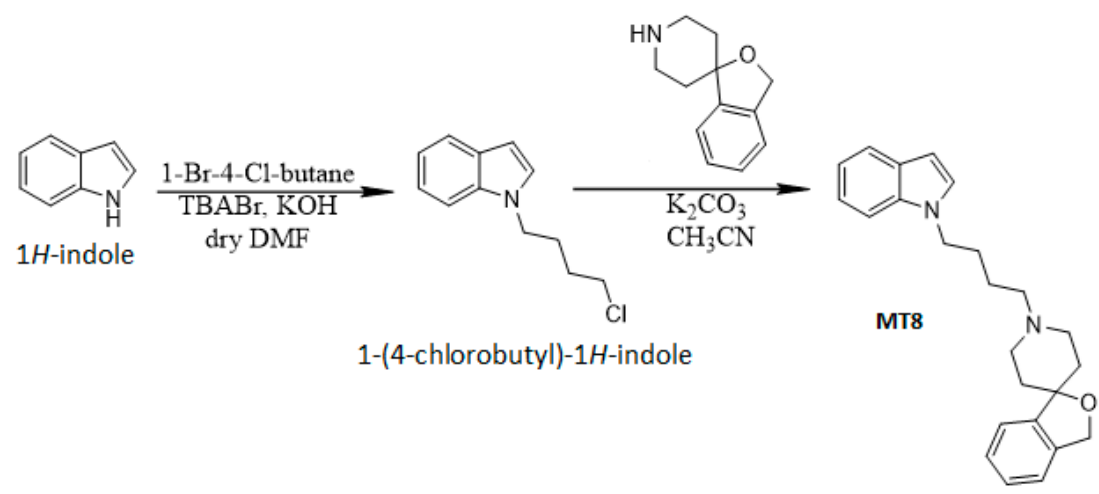

Scheme 1. Schematic representation of the MT8 synthesis.

Table 1. $\sigma$ receptor binding affinities and PANC-1 cell line viability of FA4 and MT8.

\begin{tabular}{cccc}
\hline \multirow{2}{*}{ Compound } & \multicolumn{2}{c}{ Binding Assay } & Cytotoxicity \\
\cline { 2 - 4 } & \multicolumn{2}{c}{$\boldsymbol{K}_{\mathbf{i}} \pm \mathbf{S D}^{\mathbf{a}} \mathbf{( n M )}$} & $\mathbf{I C}_{\mathbf{5 0}} \pm \mathbf{S D}^{\mathbf{a}}(\boldsymbol{\mu M} \mathbf{M})$ \\
\cline { 2 - 4 } & $\boldsymbol{\sigma 1}$ & $0.43 \pm 0.1$ & PANC-1 \\
\hline MT8 & $27.3 \pm 2.6^{\mathrm{b}}$ & $15.8 \pm 3.4$ & $19.1 \pm 1.3$ \\
FA4 & $51.3 \pm 2.5^{\mathrm{b}}$ & $12.6 \pm 1.4$ & $3.01 \pm 0.9^{\mathrm{c}}$ \\
Siramesine & $10.5 \pm 1.3^{\mathrm{d}}$ & $29.5 \pm 3.3$ & $>50$ \\
DTG & $29.3 \pm 4.3^{\mathrm{b}}$ & nd & $>50$ \\
(+)-pentazocine & $3.9 \pm 0.3^{*}$ & $>50$ \\
\hline
\end{tabular}

a Values represent the mean of $\mathrm{n} \geq 3$ separate experiments in duplicate $\pm \mathrm{SEM}^{\mathrm{b}}{ }^{\text {value obtained by flow cytometry }}$ assay with a fluorescent ligand as described in [10]; ${ }^{\mathrm{c}}$ value obtained from [10]; ${ }^{\mathrm{d}}$ value obtained from [22].

These data also suggest how the thiosemicarbazone portion on this scaffold was slightly detrimental for the interaction with the $\sigma 2$ binding site, although FA4 retained an optimal binding profile in the nanomolar range $\left(K_{\mathrm{i}}=15.8 \mathrm{nM}\right.$ for the $\sigma 1$ and $K_{\mathrm{i}}=51.3 \mathrm{nM}$ for the $\sigma 2$ receptors, respectively, Table 1). MT8 was evaluated for its anticancer properties in the PANC-1 cell line, in which FA4 activity appeared promising, both in vitro and in vivo [10]. MT8 had an appreciable cytotoxic effect in the low micromolar range $\left(\mathrm{IC}_{50}=19.1 \mu \mathrm{M}\right)$, but it was six-fold less potent than FA4.

The cytotoxicity of MT8 was also evaluated in other cancer cell lines, such as the lung adenocarcinoma A549 cells, the breast adenocarcinoma MCF7 cells, and the hepatocarcinoma HepG2 cells, displaying an $\mathrm{IC}_{50}=4.29 \mu \mathrm{M}$ in $\mathrm{A} 549, \mathrm{IC}_{50}=6.02 \mu \mathrm{M}$ in $\mathrm{MCF}$, and $\mathrm{IC}_{50}=3.20 \mu \mathrm{M}$ in HepG2 cells. These data highlight the higher aggressiveness of PANC-1 cells, in which MT8 displayed the lowest potency. On the other hand, the data also confirmed the need for a strategy with a greater impact on pancreatic tumors. From this perspective, the multitarget FA4 appeared to be a promising candidate and was selected to be further investigated in the primary PDAC cell cultures of the present study.

\subsection{Antiproliferative Activity}

Cell viability upon exposure to FA4 was measured with the Sulforhodamine B (SRB) assay. FA4 caused a concentration-dependent inhibition of proliferation (Figure 3), with IC50 values of $0.825 \pm 0.006$ and $0.701 \pm 0.059 \mu \mathrm{M}$ in the PDAC- 1 and PDAC-2 cells, respectively (Table 2). Lastly, we performed additional experiments to evaluate the in vitro cytotoxicity of FA4 against normal HPDE cells and normal fibroblast Hs27 cells. The results of these studies allowed us to calculate the selectivity index (SI, calculated as IC50 nontumor cells/IC50 tumor cells), which were 11 and 7 in HPDE and Hs27 cells, respectively. 
Interestingly, FA4 had SI values similar to the values measured for gemcitabine, as reported in previous studies in the same PDAC primary cells [23].

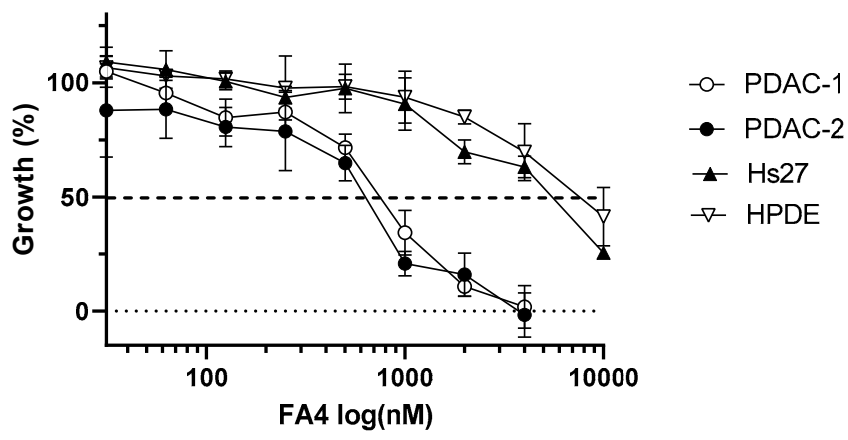

Figure 3. Representative dose-dependent inhibition of cell growth by FA4 in the PDAC primary cell lines PDAC-1 and PDAC-2 and in the HPDE and Hs27 cells. Cell viability was determined using the SRB assay after $72 \mathrm{~h}$ of treatment with increasing concentrations of FA4. Data points represent mean percentage of cell growth \pm SD of three independent experiments.

Table 2. IC50 of FA4 in primary PDAC cells and nontransformed cells.

\begin{tabular}{cc}
\hline & Cytotoxicity \\
\cline { 2 - 2 } Cell Line & $\mathbf{I C}_{\mathbf{5 0}} \pm \mathbf{S D}(\boldsymbol{\mu M})$ \\
\hline PDAC1 & $0.825 \pm 0.006$ \\
PDAC2 & $0.701 \pm 0.059$ \\
HPDE & $8.069 \pm 0.302$ \\
Hs27 & $5.551 \pm 0.333$ \\
\hline
\end{tabular}

Of note, the IC50 values of FA4 in PDAC-1 and PDAC-2 cells were lower than the values reported in human commercial PDAC cell lines, namely BxPC3, AspC1, MiaPaCa2, and PANC-1, where they ranged between $0.88 \mu \mathrm{M}$ and $3.01 \mu \mathrm{M}$ [10].

IC50 values \pm SD were determined by the graphical interpolation of the dose-response curves reported in Figure 3.

\subsection{Apoptosis Induction}

Previous studies reported that the modulation of $\sigma 2$ receptor activity contributes to the initiation of the apoptotic process [4,10]. Therefore, we evaluated the effect of FA4 on the induction of apoptosis in the PDAC primary cultures. To this aim, we measured the externalization of the plasma membrane phosphatidylserine, a reliable marker of cell apoptosis, which was quantified by the measurement of the fluorescence of annexin-V by spectrophotometric assay and microscopy. After $24 \mathrm{~h}$ of treatment with $10 \mu \mathrm{M}$ FA4, a significant increase in the portion of apoptotic cells was observed compared to untreated control cells. The highest apoptotic index was measured in the PDAC-2 cells (17.6 \pm 3.6, compared to $15.5 \pm 4.9$ in the PDAC-1 cells).

Remarkably, the percentages of apoptotic cells after treatment with FA4 were significantly higher compared to the number of cells that underwent apoptosis after treatment with gemcitabine at $10 \mu \mathrm{M}$ (Figure 4), indicating that FA4 had superior anticancer activity.

\subsection{Migration Assay}

Cancer cell migration is a key factor contributing to the aggressiveness of PDAC. It is therefore important to find new compounds that can counteract or stop this process [24]. To evaluate the effect of FA4 on cell migratory properties, a migration assay was performed by incubating cells for $24 \mathrm{~h}$ with FA4. As reported in Figure 5 and Supplemental Figure S2, the compound was able to inhibit migration over $24 \mathrm{~h}$ with respect to the control and 
had an antimigratory activity superior to previous data with gemcitabine in these PDAC cell cultures $[25,26]$.
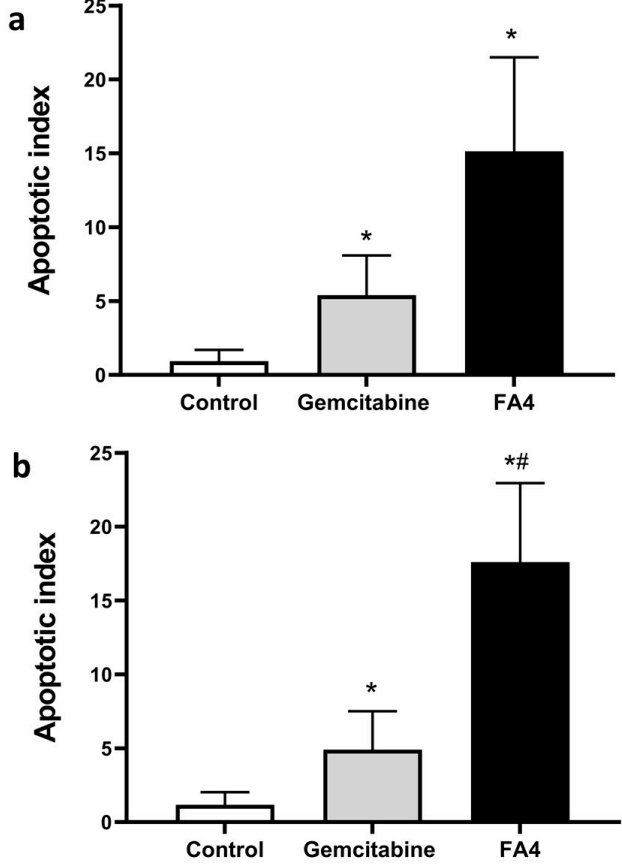

C

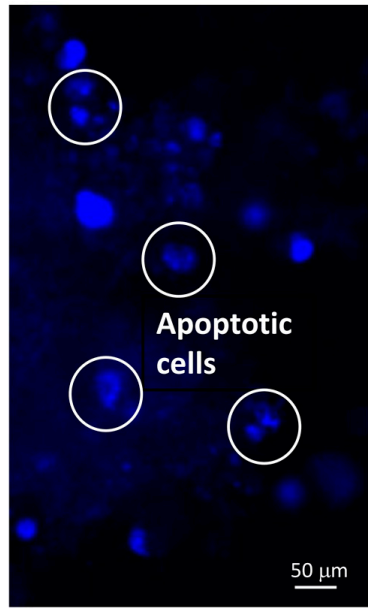

Figure 4. Effects of FA4, on apoptosis induction in PDAC-1 (a) and PDAC-2 (b) pancreatic cancer cells. The apoptotic index was calculated by evaluating the annexinV-FITC fold change compared to control cells after $24 \mathrm{~h}$ treatment. Gemcitabine was used as a positive control. Columns represent the mean; bars represent the SD. (c) Representative pictures of PDAC-2 cells with apoptotic features as assessed by bisbenzimide staining after treatment with FA4. ${ }^{*} p<0.05$, significantly different compared with control; ${ }^{\#} p<0.05$, significantly different compared with gemcitabine.

a

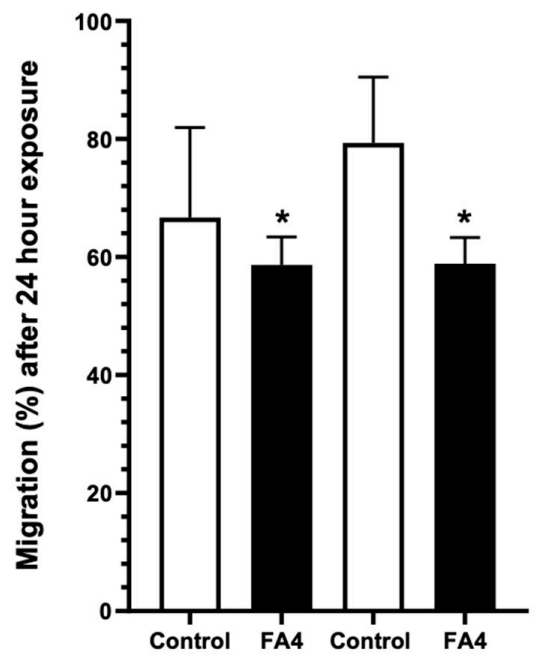

b

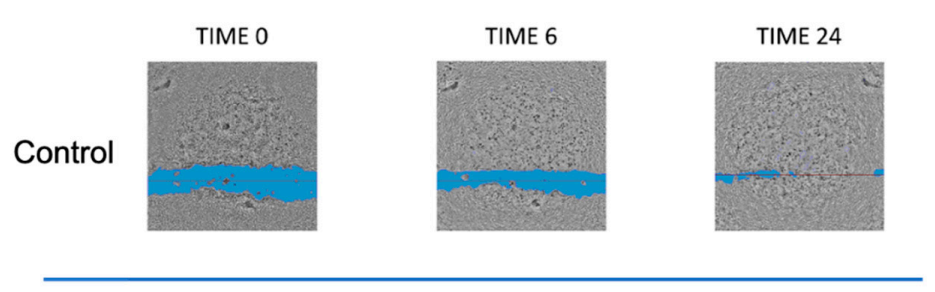

FA4
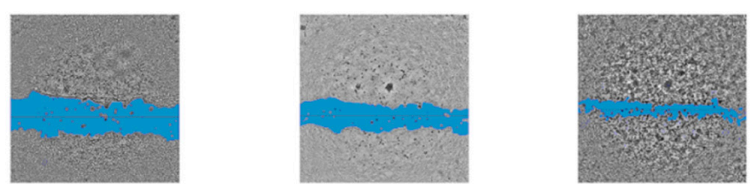

Figure 5. Results of the migration assay performed by incubating confluent cells after the scratch with FA4 $10 \mu \mathrm{M}$ in the PDAC-1 and PDAC-2 cells (a), and representative pictures taken at different time points $(0,6$, and $24 \mathrm{~h})$ in PDAC-2 cells $(\mathbf{b})$. Data are derived from three independent experiments. Columns represent the mean values obtained from three independent experiments in treated and untreated (control) cells; bars represent the SD; asterisks indicate the statistical significance compared to the control. ${ }^{*} p<0.05$. 


\section{Discussion}

PDAC is a highly aggressive tumor, and therapeutic options are limited by constitutive and acquired resistance to treatment. In the search for a novel way to improve this dismal scenario, $\sigma 2$ receptors have recently demonstrated encouraging results both in vitro and in vivo, showing the efficacy of novel compounds such as FA4 especially in PDAC cells resistant to gemcitabine [10]. To further define the potentiality of this promising drug, we studied the activity of FA4 in primary patient-derived cell cultures. These PDAC preclinical models, mimicking the molecular complexity of the original PDAC tumors, represent an improvement for the experimental testing of anticancer agents and might reduce their failure in follow-up clinical trials [16].

First, we found that the $\sigma 2$ receptor/TMEM97 gene was significantly upregulated compared to normal pancreatic epithelial cells, particularly in patient-derived cell lines with particular aggressiveness [16]. This observation prompted us to investigate how 02 receptor-targeting agents performed compared to gemcitabine, currently used as first-line therapy, with a special focus on advanced and chemorefractory tumors, where the efficacy of gemcitabine is low [3].

Following a multi-targeting drug synthesis approach, we designed a series of $\sigma 2$ receptor agonists [21]. A preliminary screening on different commercial PDAC cell lines, indicated FA4, based on the modification of the structure of $\sigma 2$ reference agonist siramesine, as the lead compound in terms of cytotoxicity [10]. By further deconstructing the siramesine structure, we produced a second congener, MT8, devoid of the thiosemicarbazone portion. Although MT8 had a higher affinity for the $\sigma 2$ receptor than FA4, its cytotoxic profile was worse in the PANC-1 cell line, while it showed a good cytotoxic profile (in the same range as FA4) in other cancer cell lines. This result suggests that the $\sigma-2$ engagement by MT8 could be responsible for part of the cytotoxicity effects, but that the presence of the thiosemicarbazone moiety in FA4 importantly improved its cytotoxicity in PDAC cells. These data are of particular interest because they were obtained in PANC-1 cells, which are typically resistant to the activity of gemcitabine [27].

Prompted by these results, we narrowed our focus to FA4 and compared its biological effects with those of gemcitabine in primary PDAC samples. First, dose-response assays to measure cell viability indicated a good antitumor effect on PDAC cell and a higher IC50 on non-transformed cells, such as pancreatic epithelial cells and fibroblasts. Second, the SI was comparable for FA4 and gemcitabine [23]. Together, these results indicated that FA4 has a potentially good therapeutic window.

Since $\sigma 2$ receptor activity is known to trigger apoptosis in PDAC cells $[4,10]$, we next tested the proapoptotic effect of FA4 in our primary PDAC cells. Interestingly, FA4 induced a higher percentage of apoptotic cells than gemcitabine. We considered that FA4 had stronger anticancer activity but the same SI of gemcitabine; hence, our results indicate that FA4 was a stronger and safer anti-PDAC agent, at least in vitro. FA4 was also safe in PDAC xenografts [10], suggesting that it could be noteworthy of further investigation in patientderived xenografts (PDXs) and in a clinical setting. Furthermore, FA4 also decreased the migration of PDAC cells, revealing another important property in the treatment of PDAC, a cancer known for its high invasiveness [24].

These results prompt further studies on the multiple effects of FA4 on primary patientderived cell cultures and PDXs and on the pharmacological effects of a co-incubation of FA4 with the drugs that represent the actual standard of care for PDAC, such as gemcitabine. Other future work will help to better clarify the pharmacokinetics and pharmacodynamics of what we hope will be a new drug in the fight against such aggressive tumor.

\section{Materials and Methods}

\subsection{Cell Culture}

Human pancreatic adenocarcinoma primary cultures (PDAC1 and PDAC2) were cultured in RPMI $+10 \%$ New Born Calf Serum $+1 \%$ Penicillin/ Streptomycin and maintained 
in standard conditions for $<20$ passages. Cells were routinely tested for Mycoplasma spp. and were free of contamination.

Human pancreatic duct epithelial-like cell line hTERT-HPNE (CRL-4023 $\left.{ }^{\mathrm{TM}}\right)$ and human skin fibroblasts Hs27 (CRL-1634 ${ }^{\mathrm{TM}}$ ), obtained from the American Type Culture Collection (ATCC ${ }^{\circledR}$, Manassas, VA, USA), were cultured in supplemented KGM medium (Lonza) and DMEM media, respectively, with $10 \%$ heat inactivated Fetal Bovine Serum (FBS) and 1\% penicillin $(100 \mathrm{mg} / \mathrm{mL})$ and streptomycin $(100 \mathrm{mg} / \mathrm{mL})$.

Previous experiments were performed with human pancreas cancer cell lines PANC-1 (CRL-1469 ${ }^{\mathrm{TM}}$ ), MiaPaCa2 (CRL-1420 ${ }^{\mathrm{TM}}$ ), BxPC-3 (CRL-1687'M $)$, PANC-02.03 (CRL-2553 ${ }^{\mathrm{TM}}$ ), AsPC-1 (CRL-1682 ${ }^{\mathrm{TM}}$ ), human A549 lung cancer cells (CRM-CCL-185 ${ }^{\mathrm{TM}}$ ), human MCF7 adenocarcinoma breast cells (HTB-22 ${ }^{\mathrm{TM}}$ ), and human HepG2 hepatocarcinoma cells (HB$8065^{\mathrm{TM}}$ ), obtained from ATCC. PANC-1, MiaPaCa2, BxPC-3, PANC-02.03, AsPC-1, and MCF7cells were cultured in DMEM with heat inactivated 10\% FBS, penicillin $(100 \mathrm{mg} / \mathrm{mL})$, and streptomycin $(100 \mathrm{mg} / \mathrm{mL})$. HepG2 cells were cultured in MEM supplemented with $10 \%(v / v)$ heat inactivated FPS, $1 \%(v / v)$ glutamine, $1 \%(v / v)$ penicillin, and streptomycin, $1 \%(v / v)$ NEAA. A549 cells were grown in HAM'S F12 supplemented with $10 \%$ heat inactivated FBS, $2 \mathrm{mM}$ glutamine, $100 \mathrm{U} \mathrm{mL}^{-1}$ penicillin, and $100 \mu \mathrm{g} / \mathrm{mL}$ streptomycin. All these cells were kept at $37^{\circ} \mathrm{C}$ in a humidified incubator under an atmosphere of $5 \%$ $\mathrm{CO}_{2}$ in $75 \mathrm{~cm}^{2}$ tissue culture flasks (Greiner Bio-One $\mathrm{GmbH}$, Frickenhausen, Germany) and were harvested with trypsin-EDTA in their exponentially growing phase.

\subsection{Evaluation of the mRNA Expression of the Gene Coding for $\sigma-2$ Receptor (TMEM97)}

RNA-sequencing analyses for PDAC-1 and PDAC-2 were performed, as described by Sciarrillo and collaborators [28]. The raw data were preprocessed for quality filtering and adapter trimming using the FASTX Toolkit (version 0.7) and subsequently mapped to the GRCh38 version of the human genome using the STAR alignment tool (version 2.5.3a). With these methods, we obtained around $90 \%$ of reads mapped to the human genome per sample. Gene counts in Fragments per Kilobase of transcript per Million mapped reads (FPKM) normalization were computed using the CuffLinks algorithm.

\section{3. $\sigma 2$ Receptor Measurement by Flow Cytometry}

Here, $1 \times 10^{6} \mathrm{HPDE}$, MiaPaCa2, PANC-1, BxPC-3, PANC-02.03, and AsPC-1 cells were incubated for $75 \mathrm{~min}$ at $37^{\circ} \mathrm{C}$ with $100 \mathrm{nM}$ of the $\sigma 2$ fluorescent ligand 2-\{6-[2-(3-(6,7dimethoxy-3,4-dihydroisoquinolin-2(1H)-yl)propyl)-3,4-dihydroisoquinolin-1(2H)-one-5yloxy]hexyl\}-5-(dimethylamino)isoindoline-1,3-dione (NO1) that completely saturated the $\sigma 2$ receptors in these experimental conditions [29]. Then, $10 \mu \mathrm{M}(+)$-pentazocine was co-incubated to mask the $\sigma 1$ receptors and detect the $\sigma 2$ receptor specific binding. After washing with PBS, cells were detached with $0.2 \mathrm{~mL}$ Cell Dissociation Solution (SigmaAldrich-RBI, Milan, Italy)), centrifuged at 13,000 $\times g$ for $5 \mathrm{~min}$, and rinsed with $0.5 \mathrm{~mL}$ PBS. The fluorescence, an index of the $\sigma 2$ receptor amount on the plasma-membrane [29], was measured on $5 \times 10^{5}$ cells, using a Guava Easy-Cyte ${ }^{\mathrm{TM}} 5$ Flow Cytometry System (Millipore, Billerica, MA, USA), with a $530 \mathrm{~nm}$ band pass filter. The results were analyzed using the InCyte software (Millipore).

\subsection{Chemical Synthesis and Analysis}

Column chromatography was performed on ICN silica gel $60 \AA(63-200 \mu \mathrm{m})$ as the stationary phase. Mass spectra were recorded with a HP GC/MS 6890-5973 MSD spectrometer, electron impact $70 \mathrm{eV}$, equipped with $\mathrm{HP}$ ChemStation. Then, ${ }^{1} \mathrm{H}-\mathrm{NMR}$ spectra were recorded in $\mathrm{CDCl}_{3}$ on a 500-vnmrs500 Agilent spectrometer $(499,801 \mathrm{MHz})$. Analytical HPLC was performed on an Agilent 1260 Infinity Binary LC System equipped with a diode array detector using a reversed phase column (Phenomenex Gemini C-18, $5 \mathrm{~mm}, 250 \times 4.6 \mathrm{~mm})$.

To synthesize 1'-(4-(1H-indol-1-yl)butyl)-3H-spiro[isobenzofuran-1,4'-piperidine] (MT8), a mixture of 1-(4-chlorobutyl)- $1 H$-indole $(100 \mathrm{mg}, 0.483 \mathrm{mmol}), 3 \mathrm{H}$-spiro[isobenzofuran-1,4'- 
piperidine] (109 mg, $0.58 \mathrm{mmol})$, and $\mathrm{K}_{2} \mathrm{CO}_{3}(80 \mathrm{mg}, 0.58 \mathrm{mmol})$ in $\mathrm{CH}_{3} \mathrm{CN}(8 \mathrm{~mL})[17,30]$ was heated at reflux overnight. After cooling, the solvent was removed under reduced pressure, and water was added to the residue. The mixture was extracted with $\mathrm{CH}_{2} \mathrm{Cl}_{2}$ $(2 \times 10 \mathrm{~mL})$ and EtOAc $(2 \times 10 \mathrm{~mL})$. The collected organic layers were dried $\left(\mathrm{Na}_{2} \mathrm{SO}_{4}\right)$ and evaporated to afford a residue, which was purified by column chromatography (1:30) with $\mathrm{CH}_{2} \mathrm{Cl}_{2} / \mathrm{MeOH}$ (95:5) as eluent to give the final compound as a yellow oil ( $30 \mathrm{mg}$, $19 \%$ yield), which was converted into the hydrochloride salt through gaseous $\mathrm{HCl}$ in Et2O. GC-MS, and 1H-NMR spectra were collected on the free base. GC-MS $m / z: 360(\mathrm{M}+, 9)$, 202 (100), 130 (12); ${ }^{1} \mathrm{H}-\mathrm{NMR}(500 \mathrm{MHz}, \mathrm{CDCl} 3) \delta: 1.55-1.65\left(\mathrm{~m}, 2 \mathrm{H}, \mathrm{NCH}_{2} \mathrm{CH}_{2}\right), 1.76\left(\mathrm{dd}^{*}\right.$, $2 \mathrm{H}, J 1=12 \mathrm{~Hz}, \mathrm{C}(\mathrm{CHH}) 2), 1.85-1.95\left(\mathrm{~m}, 2 \mathrm{H}, \mathrm{NCH}_{2} \mathrm{CH}_{2} \mathrm{CH}_{2}\right), 1.99(\mathrm{dt}, 2 \mathrm{H}, J 1=12 \mathrm{~Hz}$, $\left.J 2=4.4 \mathrm{~Hz}, \mathrm{C}(\mathrm{CHH})_{2}\right), 2.35-2.45\left(\mathrm{~m}, 4 \mathrm{H},(\mathrm{CHH})_{2} \mathrm{NCH}_{2}\right), 2.80-2.84\left(\mathrm{~m}, 2 \mathrm{H},(\mathrm{CHH})_{2} \mathrm{~N}\right) 4.17$ $\left(\mathrm{t}, 2 \mathrm{H}, J=7.3 \mathrm{~Hz}, \mathrm{NCH}_{2}\right), 5.05\left(\mathrm{~s}, 2 \mathrm{H}, \mathrm{OCH}_{2} \mathrm{Ar}\right), 6.49(\mathrm{~d}, 1 \mathrm{H}, J=2.9 \mathrm{~Hz}$, aromatic), 7.08-7.29 $(\mathrm{m}, 7 \mathrm{H}$, aromatic), $7.37(\mathrm{~d}, 1 \mathrm{H}, J=7.82 \mathrm{~Hz}$, aromatic), $7.63(\mathrm{~d}, 1 \mathrm{H}, J=7.82 \mathrm{~Hz}$, aromatic). * 2 could not be calculated from the spectrum as it was too small. Hydrochloride salt was $>98 \%$ pure by HPLC analysis performed by isocratic elution with $\mathrm{CH}_{3} \mathrm{CN} / \mathrm{HCOONH}_{4}$ $(20 \mathrm{mM}, \mathrm{pH}=5) 80: 20 \mathrm{v} / \mathrm{v}$, at a flowrate of $1 \mathrm{~mL} / \mathrm{min}$.

\subsection{Radioligand Binding Assays}

$\sigma 1$ and $\sigma 2$ receptor binding were carried out following Matsumoto et al. [31]. [ $\left.{ }^{3} \mathrm{H}\right]-\mathrm{DTG}$ $(30 \mathrm{Ci} / \mathrm{mmol})$ and $(+)-\left[{ }^{3} \mathrm{H}\right]$-pentazocine $(34 \mathrm{Ci} / \mathrm{mmol})$ were purchased from PerkinElmer Life Sciences (Zavantem, Belgium). DTG was purchased from Tocris Cookson Ltd. (Bristol, UK). (+)-Pentazocine was obtained from Sigma-Aldrich-RBI. All the procedures for the binding assays were described previously by Abate and collaborators [32].

\subsection{Sulforhodamine-B (SRB) Assay}

Cells were seeded in 96-well flat-bottom plates at a density of 3000/well, using both a control plate and an experimental plate. After $24 \mathrm{~h}$, the control plate was fixed with cold $50 \%$ trichloroacetic acid, and the incubation with the compound of interest was performed in the experimental plate. After $72 \mathrm{~h}$ of incubation, the experimental plate was also fixed. Subsequently, both plates were washed and stained with the SRB solution, and after vigorous washing and drying, the bound dye was extracted from the cells with an alkaline solution. The absorption of SRB was measured spectrophotometrically at a wavelength of $490 \mathrm{~nm}$ and $540 \mathrm{~nm}$. The intensity of the signal is proportional to the number of living cells and, therefore, a measure of their proliferation. Thus, cell growth inhibition was calculated as the percentage versus vehicle-treated cells ("negative control") OD (corrected for OD of the control plate before drug addiction). Finally, the half maximal inhibitory concentration (IC50) was calculated by nonlinear least squares curve fitting (GraphPad Prism 7, Intuitive Software for Science, San Diego, CA, USA), as described previously [33]. The SRB assay was performed in technical and biological triplicates.

\subsection{Apoptosis Assay}

Cells were seeded in 96-well plates $\left(5 \times 10^{3}\right.$ cells/well), and after $24 \mathrm{~h}$, the cells were fixed with $4 \%$ paraformaldehyde in PBS for $30 \mathrm{~min}$, then washed twice with PBS and stained with annexinV-FITC in binding buffer (10 mM HEPES/ NaOH pH 7.4, $140 \mathrm{mM}$ $\mathrm{NaCl}$, and $2.5 \mathrm{mM} \mathrm{CaCl}_{2}$ ) for $10 \mathrm{~min}$ in the dark at room temperature. Lastly, cells were washed with the assay binding buffer solution, and fluorescence was measured by using a multimode plate reader with excitation and emission filters at $485 \mathrm{~nm}$ and $535 \mathrm{~nm}$, respectively, to determine the apoptotic index. The values were normalized considering the cell proliferation as assessed by crystal violet assay, as described previously [34]. Cells were also stained with $8 \mu \mathrm{g} / \mathrm{mL}$ bisbenzimide to detect typical apoptotic morphological features, as described previously [35]. 


\subsection{Migration Assay}

Cells were seeded into 96-well plates $72 \mathrm{~h}$ before the assay at a density of $5 \times 10^{4}$ /well and allowed to attach and to become confluent. Subsequently, a scratch was performed in every well with a 96-pin scratcher, allowing the formation of uniform scratches. Immediately after this passage, cells were cultured for $24 \mathrm{~h}$ in complete medium with the drug of interest for experimental wells or without any drug for the control wells. Pictures were taken with an optical microscope at different time points $(0,6$, and $24 \mathrm{~h})$ and analyzed with the Scratch Assay 6.2 software (Digital Cell Imaging Labs, Keerbergen, Belgium). The migration assay was performed in technical and biological triplicates, as reported previously [35].

\subsection{Statistical Analysis}

All the assays were carried out in triplicate and repeated at least three times, whereas the percentages of apoptotic cells were calculated taking into account at least three biological replicates. The data were evaluated using GraphPad Prism 9.0 (GraphPad Software, San Diego, CA, USA). Data were analyzed by applying the one-way repeated measures analysis of variance and Bonferroni's multiple comparison test as a post hoc test. The results were reported as mean \pm SD (standard deviation), and statistical significance was accepted at $p<0.05$.

Supplementary Materials: The following supporting information can be downloaded at: www mdpi.com/xxx/s1, Figure S1: Amount of plasma-membrane associated $\sigma 2$-receptor on pancreatic cancer cells and non-transformed pancreatic epithelial cells; Figure S2: Results of the migration assay performed in PDAC-1 cells.

Author Contributions: M.N. and F.S.A. performed chemical research and analyzed the data. D.P.A., A.P., A.A. and S.M.F.R. performed biological research and analyzed the data. C.A., C.R. and E.G. participated in the design of the research and the writing of the manuscript. All authors have read and agreed to the published version of the manuscript.

Funding: This work was partially supported by the following grants: CCA Foundation 2018 grants (to E.G.), KWF Dutch Cancer Society grants (KWF project\#19571) (to E.G.); AIRC IG grant 24444 (to E.G.) and IG grant 21408 (to C.R.); CRT Foundation 2021 (\#2021-0556 to C.R.); EU Social Fund (FSE) and the Canary Islands ACIISI predoctoral grant TESIS2020010055 and EST2021010019 (to A.P) D.P.A. was supported by the COST Action CA17104 STRATAGEM, supported by COST (European Cooperation in Science and Technology) (www.cost.eu).

Acknowledgments: We acknowledge the contribution of Camilla Pecoraro (University of Palermo and Amsterdam UMC) and Francesca Masetto (University of Verona and Amsterdam UMC) in the preliminary studies on the apoptosis assay, and the members of the COST Action STRATAGEM and of the EORTC-PAMM group for the fruitful discussion.

Conflicts of Interest: The authors declare no conflict of interest.

Sample Availability: Samples of the compound FA4 are available from the authors.

\section{References}

1. GBD 2017 Pancreatic Cancer Collaborators. The global, regional, and national burden of pancreatic cancer and its attributable risk factors in 195 countries and territories, 1990-2017: A systematic analysis for the Global Burden of Disease Study 2017. Lancet Gastroenterol. Hepatol. 2019, 4, 934-947. [CrossRef]

2. Rahib, L.; Wehner, M.R.; Matrisian, L.M.; Nead, K.T. Estimated projection of US cancer incidence and death to 2040. JAMA Netw. Open 2021, 4, e214708. [CrossRef] [PubMed]

3. American Cancer Society. Pancreatic Cancer. Available online: https://www.cancer.org/cancer/pancreatic-cancer.html (accessed on 24 October 2021).

4. Zeng, C.; Rothfuss, J.; Zhang, J.; Chu, W.; Vangveravong, S.; Tu, Z.; Pan, F.; Chang, K.C.; Hotchkiss, R.; Mach, R.H. Sigma-2 Ligands Induce Tumour Cell Death by Multiple Signalling Pathways. Br. J. Cancer 2012, 106, 693-701. [CrossRef]

5. Mach, R.H.; Zeng, C.; Hawkins, W.G. The $\sigma_{2}$ Receptor: A Novel Protein for the Imaging and Treatment of Cancer. J. Med. Chem. 2013, 56, 7137-7160. [CrossRef] [PubMed] 
6. Su, T.P.; Su, T.C.; Nakamura, Y.; Tsai, S.Y. The Sigma-1 receptor as a pluripotent modulator in living systems. Trends Pharmacol. Sci. 2016, 37, 262-278. [CrossRef]

7. Alon, A.; Schmidt, H.R.; Wood, M.D.; Sahn, J.J.; Martin, S.F.; Kruse, A.C. Identification of the Gene That Codes for the $\sigma 2$ Receptor Proc. Natl. Acad. Sci. USA 2017, 114, 7160-7165. [CrossRef]

8. Alon, A.; Lyu, J.; Braz, J.M.; Tummino, T.A.; Craik, V.; O’Meara, M.J.; Webb, C.M.; Radchenko, D.S.; Moroz, Y.S.; Huang, X.P.; et al. Structures of the $\sigma 2$ receptor enable docking for bioactive ligand discovery. Nature 2021, 600, 759-764. [CrossRef]

9. Cheng, Y.S.; Zhang, T.; Ma, X.; Pratuangtham, S.; Zhang, G.C.; Ondrus, A.A.; Mafi, A.; Lomenick, B.; Jones, J.J.; Ondrus, A.E A proteome-wide map of 20(S)-hydroxycholesterol interactors in cell membranes. Nat. Chem. Biol. 2021, 17, 1271-1280. [CrossRef]

10. Niso, M.; Kopecka, J.; Abatematteo, F.S.; Berardi, F.; Riganti, C.; Abate, C. Multifunctional Thiosemicarbazones Targeting Sigma Receptors: In Vitro and in Vivo Antitumor Activities in Pancreatic Cancer Models. Cell. Oncol. 2021, 44, 1307-1323. [CrossRef]

11. Hornick, J.R.; Spitzer, D.; Goedegebuure, P.; Mach, R.H.; Hawkins, W.G. Therapeutic Targeting of Pancreatic Cancer Utilizing Sigma-2 Ligands. Surgery 2012, 152, S152-S156. [CrossRef]

12. Pati, M.L.; Hornick, J.R.; Niso, M.; Berardi, F.; Spitzer, D.; Abate, C.; Hawkins, W. Sigma-2 receptor agonist derivatives of 1-Cyclohexyl-4-[3-(5-methoxy-1,2,3,4-tetrahydronaphthalen-1-yl)propyl]piperazine (PB28) induce cell death via mitochondrial superoxide production and caspase activation in pancreatic cancer. BMC Cancer 2017, 17, 51. [CrossRef] [PubMed]

13. Rovithi, M.; Avan, A.; Funel, N.; Leon, L.G.; Gomez, V.E.; Wurdinger, T.; Griffioen, A.W.; Verheul, H.M.W.; Giovannetti, E. Development of Bioluminescent Chick Chorioallantoic Membrane (CAM) Models for Primary Pancreatic Cancer Cells: A Platform for Drug Testing. Sci. Rep. 2017, 7, 44686. [CrossRef] [PubMed]

14. Ciccolini, J.; Serdjebi, C.; Peters, G.J.; Giovannetti, E. Pharmacokinetics and Pharmacogenetics of Gemcitabine as a Mainstay in Adult and Pediatric Oncology: An EORTC-PAMM Perspective. Cancer Chemother. Pharmacol. 2016, 78, 1-12. [CrossRef] [PubMed]

15. Le Large, T.Y.S.; Bijlsma, M.F.; Kazemier, G.; van Laarhoven, H.W.M.; Giovannetti, E.; Jimenez, C.R. Key Biological Processes Driving Metastatic Spread of Pancreatic Cancer as Identified by Multi-Omics Studies. Semin. Cancer Biol. 2017, 44, 153-169. [CrossRef] [PubMed]

16. Avan, A.; Caretti, V.; Funel, N.; Galvani, E.; Maftouh, M.; Honeywell, R.J.; Lagerweij, T.; Van Tellingen, O.; Campani, D.; Fuchs, D.; et al. Crizotinib Inhibits Metabolic Inactivation of Gemcitabine in C-Met-Driven Pancreatic Carcinoma. Cancer Res. 2013, 73, 6745-6756. [CrossRef]

17. Pati, M.L.; Niso, M.; Spitzer, D.; Berardi, F.; Contino, M.; Riganti, C.; Hawkins, W.G.; Abate, C. Multifunctional Thiosemicarbazones and Deconstructed Analogues as a Strategy to Study the Involvement of Metal Chelation, Sigma-2 ( $\sigma 2)$ Receptor and P-gp Protein in the Cytotoxic Action: In Vitro and in Vivo Activity in Pancreatic Tumors. Eur. J. Med. Chem. 2018, 144, 359-371. [CrossRef]

18. Pati, M.L.; Niso, M.; Ferorelli, S.; Abate, C.; Berardi, F. Novel Metal Chelators Thiosemicarbazones with Activity at the $\sigma_{2}$ Receptors and P-Glycoprotein: An Innovative Strategy for Resistant Tumor Treatment. RSC Adv. 2015, 5, 103131-103146. [CrossRef]

19. Schmidt, H.R.; Kruse, A.C. The Molecular Function of $\sigma$ Receptors: Past, Present, and Future. Trends Pharmacol. Sci. 2019, 40, 636-654. [CrossRef]

20. Fallica, A.N.; Pittalà, V.; Modica, M.N.; Salerno, L.; Romeo, G.; Marrazzo, A.; Helal, M.A.; Intagliata, S. Recent Advances in the Development of Sigma Receptor Ligands as Cytotoxic Agents: A Medicinal Chemistry Perspective. J. Med. Chem. 2021, 64, 7926-7962. [CrossRef]

21. Abatematteo, F.S.; Niso, M.; Lacivita, E.; Abate, C. $\sigma 2$ Receptor and Its Role in Cancer with Focus on a MultiTarget Directed Ligand (MTDL) Approach. Molecules 2021, 26, 3743. [CrossRef]

22. Niso, M.; Abate, C.; Contino, M.; Ferorelli, S.; Azzariti, A.; Perrone, R.; Colabufo, N.A.; Berardi, F. Sigma-2 Receptor Agonists as Possible Antitumor Agents in Resistant Tumors: Hints for Collateral Sensitivity. ChemMedChem 2013, 8, 2026-2035. [CrossRef] [PubMed]

23. Cascioferro, S.; Petri, G.L.; Parrino, B.; Carbone, D.; Funel, N.; Bergonzini, C.; Mantini, G.; Dekker, H.; Geerke, D.; Peters, G.J.; et al Imidazo[2,1-b] [1,3,4]Thiadiazoles with Antiproliferative Activity against Primary and Gemcitabine-Resistant Pancreatic Cancer Cells. Eur. J. Med. Chem. 2020, 189, 112088. [CrossRef] [PubMed]

24. Giovannetti, E.; van der Borden, C.L.; Frampton, A.E.; Ali, A.; Firuzi, O.; Peters, G.J. Never Let It Go: Stopping Key Mechanisms Underlying Metastasis to Fight Pancreatic Cancer. Semin. Cancer Biol. 2017, 44, 43-59. [CrossRef] [PubMed]

25. Giovannetti, E.; Wang, Q.; Avan, A.; Funel, N.; Lagerweij, T.; Lee, J.-H.; Caretti, V.; van der Velde, A.; Boggi, U.; Wang, Y.; et al. Role of CYB5A in Pancreatic Cancer Prognosis and Autophagy Modulation. J. Natl. Cancer Inst. 2014, 106, djt346. [CrossRef] [PubMed]

26. Le Large, T.Y.S.; Bijlsma, M.F.; El Hassouni, B.; Mantini, G.; Lagerweij, T.; Henneman, A.A.; Funel, N.; Kok, B.; Pham, T.V.; de Haas, R.; et al. Focal Adhesion Kinase Inhibition Synergizes with Nab-Paclitaxel to Target Pancreatic Ductal Adenocarcinoma. J. Exp. Clin. Cancer Res. 2021, 40, 91. [CrossRef]

27. Masetto, F.; Chegaev, K.; Gazzano, E.; Mullappilly, N.; Rolando, B.; Arpicco, S.; Fruttero, R.; Riganti, C.; Donadelli, M. MRP5 nitration by NO-releasing gemcitabine encapsulated in liposomes confers sensitivity in chemoresistant pancreatic adenocarcinoma cells. Biochim. Biophys. Acta Mol. Cell Res. 2020, 1867, 118824. [CrossRef]

28. Sciarrillo, R.; Wojtuszkiewicz, A.; Kooi, I.E.; Gómez, V.E.; Boggi, U.; Jansen, G.; Kaspers, G.-J.; Cloos, J.; Giovannetti, E. Using RNA-Sequencing to Detect Novel Splice Variants Related to Drug Resistance in In Vitro Cancer Models. J. Vis. Exp. 2016, 9, 54714. [CrossRef] 
29. Niso, M.; Riganti, C.; Pati, M.L.; Ghigo, D.; Berardi, F.; Abate, C. Novel and Selective Fluorescent $\sigma 2$-Receptor Ligand with a 3,4-Dihydroisoquinolin-1-one Scaffold: A Tool to Study $\sigma 2$ Receptors in Living Cells. Chembiochem 2015, 16, 1078-1083. [CrossRef]

30. Perregaard, J.; Moltzen, E.K.; Meier, E.; Sanchez, C. Sigma Ligands with Subnanomolar Affinity and Preference for the Sigma.2 Binding Site. 1. 3-(Omega-Aminoalkyl)-1H-Indoles. J. Med. Chem. 1995, 38, 1998-2008. [CrossRef]

31. Matsumoto, R.R.; Bowen, W.D.; Tom, M.A.; Vo, V.N.; Truon, D.D.; De Costa, B.R. Characterization of Two Novel $\sigma$-Receptor Ligands: Antidystonic Effects in Rats Suggest $\sigma$-Receptor Antagonism. Eur. J. Pharmacol. 1995, 280, 301-310. [CrossRef]

32. Abate, C.; Niso, M.; Lacivita, E.; Mosier, P.D.; Toscano, A.; Perrone, R. Analogues of $\sigma$ Receptor Ligand 1-Cyclohexyl-4-[3-(5Methoxy-1,2,3,4-Tetrahydronaphthalen-1-yl)Propyl]Piperazine (PB28) with Added Polar Functionality and Reduced Lipophilicity for Potential Use as Positron Emission Tomography Radiotracers. J. Med. Chem. 2011, 54, 1022-1032. [CrossRef] [PubMed]

33. Le Large, T.Y.S.; Mantini, G.; Meijer, L.L.; Pham, T.V.; Funel, N.; van Grieken, N.C.T.; Kok, B.; Knol, J.; van Laarhoven, H.W.M.; Piersma, S.R.; et al. Microdissected Pancreatic Cancer Proteomes Reveal Tumor Heterogeneity and Therapeutic Targets. JCI Insight 2020, 5, e138290. [CrossRef] [PubMed]

34. Pecoraro, C.; Parrino, B.; Cascioferro, S.; Puerta, A.; Avan, A.; Peters, G.J.; Diana, P.; Giovannetti, E.; Carbone, D. A New Oxadiazole-Based Topsentin Derivative Modulates Cyclin-Dependent Kinase 1 Expression and Exerts Cytotoxic Effects on Pancreatic Cancer Cells. Molecules 2021, 27, 19. [CrossRef] [PubMed]

35. Massihnia, D.; Avan, A.; Funel, N.; Maftouh, M.; van Krieken, A.; Granchi, C.; Raktoe, R.; Boggi, U.; Aicher, B.; Minutolo, F.; et al. Phospho-Akt Overexpression Is Prognostic and Can Be Used to Tailor the Synergistic Interaction of Akt Inhibitors with Gemcitabine in Pancreatic Cancer. J. Hematol. Oncol. 2017, 10, 9. [CrossRef] [PubMed] 